FACTA UNIVERSITATIS

Series: Linguistics and Literature Vol. 17, $\mathrm{N}^{\mathrm{o}} 1,2019$, pp. 1-9

https://doi.org/10.22190/FULL1901001P

Review Paper

\title{
NATURE IN MONTAIGNE AND EMERSON
}

\author{
UDC 821.133.1.09 Montaigne M. \\ 821.111(73).09 Emerson R. W.
}

\section{Svetozar Poštić}

Vilnius University, Faculty of Philology, Lithuania

\begin{abstract}
Ralph Waldo Emerson was an ardent admirer of Michel de Montaigne, his 16th-century French predecessor. He was indebted to his fellow writer and philosopher for both content and style. Moreover, it could be argued that Montaigne influenced Emerson's worldview as well. They have both been called naturalists by the critics for their theoretic outlook, but their naturalisms have never been linked as their guiding philosophical conviction. Both Montaigne and Emerson praised nature and everything "natural," including humans, and saw nature imbued with a guiding, omnipotent spirit. Influenced by the poets and philosophers of antiquity, his intellectual guiding lights, Montaigne used the words "nature" and "God" interchangeably, while Emerson suffused nature with a divine essence. Both writers thus contributed to the disenchantment of the world and depersonalization of the once divinized Creator.
\end{abstract}

Key Words: Montaigne, Emerson, nature, naturalism

\section{INTRODUCTION}

In his book Representative Men, Ralph Waldo Emerson, the19th-century American writer and philosopher, positioned Michel de Montaigne, the16th-century French essayist, alongside Plato, Shakespeare and Goethe. In the title of the essay on Montaigne, Emerson calls him "The Skeptic." Why did he not name Montaigne 'the essayist', as would have been more in accordance with the characterization of other notable people (e.g. Plato, the Philosopher; Shakespeare, the Poet; Goethe, the Writer)? As Pamela Shirmeister (1995, xxiii) suggests in the Introduction to the collection, Emerson might have left this title and honor for himself. Montaigne's Essais, which gave a name to the new (or revived) genre, are true "trials, experiments," as another meaning of the French word indicates. Emerson did not explain the influence Montaigne's writing had on him, but it is evident that his texts resemble Montaigne's essays in form, language, structure and content.

Submitted November 10, 2018; Accepted February 17, 2019

Corresponding author: Svetozar Poštić

Vilnius University, Faculty of Philology

E-mail: svetozarpostic@gmail.com 
Montaigne's influence on Emerson goes beyond genre and common themes. It seems that Montaigne's worldview was amply adopted by his American admirer. Emerson is known for professing individualism and self-reliance, values which defined the acculturation of the European settlers in the New World, and Montaigne's writing is revolutionary in abandoning the common literary and philosophical themes, and turning toward a psychological analysis of oneself. The concept which perhaps best describes the cosmological understanding of both essayists is the idea of Nature.

In philosophy, Naturalism represents the idea that only natural (as opposed to supernatural or spiritual) laws and forces operate in the world. In literature, Naturalism is a branch of realism which prefers observation to emotional and psychological analysis. The two concepts are related because they both favour fact, logic, and impersonality over the imaginative, symbolic, and supernatural. In this paper, we attach an additional ideological nuance to this concept. Contemporary thinkers tend to consider nature as the source and cause of our existence - a more rational and observable creator and life-giver which has gradually replaced God in an increasingly anthropocentric and individualistic world. Both Montaigne and Emerson can be considered naturalists for examining and interpreting observable nature, including human nature, and for detaching themselves from the teleological inclinations predominant in the Christian tradition.

In this paper, after exploring some of the more general similarities between the two writers, we concentrate on the concept of nature in the writings of both Montaigne and Emerson, and on the attempts to underline its common philosophical nucleus. Our main argument is that they both contributed to the replacement of God by nature as the overarching concept of a life-giving and world-shaping force. Emerson adopted some of Montaigne's notions and, unrestrained by the precarious theological and political environment, in a world more open to novel ideas, took them a step further.

\section{EMERSON ON MONTAIGNE}

In Representative Men, a collection of essays on the giants of culture he admired most, Emerson introduces Montaigne by describing his encounter with the translation of Essays, which "so sincerely spoke to my thoughts and experience" (Emerson 1995, 110). Although a man of pleasure, Montaigne had studious habits, Emerson notes. He was esteemed for his "sense of probity," and he was fearless and liberal (Emerson 1995, 111112). Montaigne is the "Frankest and honestest of all writers," Emerson declares (Emerson 1995, 112). He tasted the life at court, but he has no qualms about talking to the low class. "There have been men with deeper insight;" Emerson writes, "but, one would say, never a man with such abundance of thoughts: he is never dull, never insincere, and has the genius to make the reader care of all that he cares for" (Emerson 1995, 144). He admired Montaigne for his vernacular language and for always being realistic.

Emerson finds common ground with Montaigne in more than one subject matter. In his essays, Emerson (1950, 351) refers to Montaignian moderation as the "mid-world," "middle region," or "temperate zone". (Montaigne 1995, 112-13), and admits having a similar trait: "I find my account in sots and bores also". (Emerson 1950, 351). They are both alike in being able to stay inside for weeks doing intellectual work, but also to set out on an adventure. "He has stayed in-doors till he is deadly sick; he will to the open air, though it rain bullets," Emerson depicts Montaigne (Montaigne 1995, 113), and similarly 
describes his own character: "I am grown by sympathy a little eager and sentimental, but leave me alone and I should relish every hour and what it brought me, the potluck of the day, as heartily as the oldest gossip in the bar-room" $(1950,351)$. Emerson proposes the same sort of emphasis on body and spirit, wisdom and pragmatism as the guiding values for the people of his own country.

One of the most striking legacies of Montaigne's Essais found in the writings of Emerson and his followers is style. The style of both writers is poetic, Emerson's probably more so, because he reverts to metaphors more often than Montaigne. Montaigne might lose his reader for a sentence or two because of a peculiar association and brevity of expression, but he quickly returns to the subject and to the previous tone. Emerson, whose essays are termed poems in prose, or prose poems, sometimes allows himself the liberty of an entirely lyrical paragraph and a topic only remotely connected to the gist of the essay. Both writers tended to finish a paragraph with an aphorism, often a quote, which is not always a continuation of the previous thought, but whose function is to establish the flow and harmony of the essay, as in "Tout ce qui est diviser jusqu'à être réduit en poussière'est que confusion" (Montaigne 2002-3,355) and "Life is not worth the taking, to do tricks in" (Emerson 1950, 349). In order to convey a message and prove his point more convincingly, Emerson adopts Montaigne's practice of alternating the discussion between the general and the personal, which sometimes goes as far as writing about everyday habits, gestures, personal preferences, even annoyances.

Emerson's and Montaigne's views on Christianity are very different, as it may seem. For Emerson, Christian faith lies on the extreme end of the abstractionist-materialist line, and should be avoided as every other fanaticism: "We must set up the strong present tense against all the rumors of wrath, past or to come" (Emerson 1950, 353). He argues that "Nature's darlings, the great, the strong the beautiful, are not children of our law, do not come out of the Sunday School, nor weigh their food, nor punctually keep their commandments" (Emerson 1950,352). Emerson believes that the pious are too weak to be great, a thought foreshadowing Nietzsche (a great admirer of Emerson, cf. Mikics 2003). By saying that "we will be strong with [Nature's] strength, we must not harbor such disconsolate consciences, borrowed too from the consciences of other nations" (Emerson 1950, 352), Emerson expresses a desire for a new spirit worthy of the great new world.

We note that a non-conformist Romantic transcendentalist who preaches self-reliance, such as Emerson, identifies himself with someone who openly accepts Christianity (“[L'homme] s'élèverasi Dieu luiprêteextraordinairement la main; ils'élèvera, abandonnant et renonçant à ses propres moyens, et se laissant hausser et soulever par les moyens purement célestes" (Montaigne 2002-2003, 351)), which can mean that either Emerson misinterpreted Montaigne, which is highly unlikely, or that the germ of Emerson's ideal of a new-spirited individualism is actually found in Montaigne's writing. The striking similarities between Montaigne's essay "De l'expérience" and Emerson's essay "Experience" may support the proposition. All in all, the human traits they both admire the most are valor, fearlessness, and intellectual integrity.

While Emerson was able to be honest about his unconventional religious views in 19th-century New England, Montaigne, pressed between the anvil of Reformation and the hammer of Counter-Reformation, appears to have been more careful. However, as many critics have argued, Montaigne's religious outlook was not only sympathetic to the Reformation movement, but also dangerously atheist (cf. Hoffman 2002; Courbet and Royer 1872-1900, v-vi). If we should believe that Emerson as a former Unitarian 
minister, and Montaigne as an ostensibly respectable Catholic moved away from the Christian doctrine, what could their religious and philosophical convictions be? We shall here focus on the understanding of Nature and the belief in Naturalism as the principal epistemological guide in the beliefs of both writers.

\section{NATURE IN MONTAIGNE}

In his Essais, Montaigne glorifies nature, devoid of human artifice, and everything natural. Montaigne talks about the beauty and truth found in nature in an almost pantheistic manner. In "Apologie" he devoted thirty pages to an attempt to prove that humans are not wiser than animals, only less "natural." In "De l'expérience," he sometimes spells the word nature with a capital $\mathrm{N}$ and ascribes to it divine attributes: "Nature les donne toujours plus heureuses que ne sont celles que nous nous donnons" (Montaigne 2002-3, 355). A little farther he says that the more simply we trust Nature, the more wisely we trust her (Montaigne 2002-3, 364), and that whatever happens contrary to the course of Nature may be disagreeable, but what happens according to her should always be pleasant (Montaigne 2002-3, 398-9) .

In "Des cannibales", Montaigne mocks the word savages, which is used to describe the pristine tribe of Tupinamba. "Ils sont sauvages," he writes, "de même que nous appelons sauvages les fruits que nature, de soi et de son progrès ordinaire, a produits : là, où, à la vérité, ce sont ceux que nous avons altérés par notre artifice et détournés de l'ordre commun, que nous devrions appeler plutôt sauvages" (Montaigne 2002-3, 3034), he explains. Montaigne's main purpose in praising the cannibals is probably to compare their virtues to the bestiality of his compatriots in the Wars of Religion. Nonetheless, this argument became very influential. In his "Discourse on the Arts and Sciences," Jean-Jacques Rousseau, congruously, contends that man is good by nature when uncorrupted by society. Zalloua $(2003,180)$ argues that with such a positive portrait of the cannibal, Montaigne has created the myth of the Noble Sauvage, which was later famously taken up by Rousseau and the Romantics Emerson was one of the Romantics who full-heartedly embraced this myth.

In the "Apologie de Raimond Sebond," his longest essay and the only one entirely dedicated to religion, Montaigne sets up the superiority of animals over humans because they are more natural (Montaigne 2002-3, 159-60). Montaigne declares the fact that natural laws exist is evident in other creatures, but we have all but lost it. As for the pronounced guidance by instincts in animals, Montaigne $(2002-2003,165)$ holds that it is more honorable and safe to conduct ourself according to nature than to our laws. Humans are born with natural instincts, but their surrounding makes them gradually lose it. The fact that his own judgment cannot make his friend accept it, for Montaigne (2002-2003, 299 ) it is a sign that he has grasped it by some other means than by "une naturelle puissance qui soitenmoi et entous les homes". With this disturbing awareness of the loss of natural condition, Montaigne depicts a void which has to be filled, so that it does not result in a nauseating existentialist apprehension.

Even though nature, not God, represents the highest authority for Montaigne, sometimes he presents the two concepts as synonyms: "Il n'est pas en notre puissance d'acquérir une plus belle recommandation que d'être favorisé de Dieu et de Nature" (2002-3, 166). He writes that it is wonderful how little Nature needs in order to be 
content. This natural simplicity and absence of lofty desires is best exemplified in the lifestyle of the newly-discovered natives of Brazil (Montaigne 2002-2003, 205), but also in French peasants, who are happier than us, and orderly without any erudition (Montaigne 2002-2003, 202). Montaigne asserts that by long study, we have confirmed the ignorance that was naturally in us, and men who have recognized vanity in all the knowledge "ontrenoncé à leurprésomption et reconnuleur condition naturelle" have renounced their presumption and accepted their natural state (Montaigne 2002-2003, 219). He regrets that ancient philosophers had not left us in our natural state presented to our through senses, but let us follow our socially-conditioned appetites (Montaigne 20022003, 271). Pyrrhonism, the school of philosophy Montaigne endorses in the "Apologie" is the only one that presents man naked and empty, and acknowledges his natural weaknesses (Montaigne 2002-2003, 256). It is a philosophy which makes the selfawareness of the thinking subject even more pronounced - a far cry from the unprejudiced relation of a simple peasant with his surroundings. Montaigne thus abandons a belief in divine towards natural laws.

In his article "The investigation of nature" George Hoffmann calls Montaigne a naturalist, on the basis of his revelation in the "Apologie". Montaigne's critique of the knowledge of causes resembles Lucretius' notion of random chance, and he sees both knowledge and action not as contingent, but simply as circumstantial (i.e. affected by context). Hoffman (2006, 171-172) argues that his thoughts on randomness follow Epicurean instead of the skeptical arguments one might expect. Namely, Montaigne prescribes Epicurus' universal disorder and its dual rejection of divine intervention and natural determinism. Philosophers of antiquity tried to eliminate fear and bring tranquility to the spirits of their adherents by elaborating their vision of the cosmos for therapeutic ends. Montaigne suggests that blind chance should not trouble anyone anymore. He seeks an explanation for natural phenomena without recourse to the teleological appeals predominant in the practice of natural theology of his day. Hoffman $(2006,173)$ contends that this attitude shifted the grounds on natural inquiry from an analysis of means and ends to the one of cause and effects. Montaigne's initiation of the first recognizable psychological study of human nature allowed Descartes' extension of the natural program to an empirical investigation of discernment and the process of judgment (Hoffmann 2006, 175-177).

This Epicurean randomness has brought an understanding of the human world full of unique historical entities, such as laws, institutions and states, which Zachary Schiffman (1991a, xii) calls "new relativism". The activity of analyzing himself satisfied Montaigne's sense of relativity without creating a skeptical denial of truth; it accorded with his awareness of limitations of his perception while, at the same time, served as a link to the reality he sought to understand. On the one hand, Schiffman $(1991 b, 76)$ claims that the approach presented all knowledge as relative to the observer; on the other, it presented the observer as an entity that could be known 'objectively'. Some of Montaigne's contemporaries were upset by his delight in a diversity which appeared chaotic to them. The essayist seemed to have such a rare degree of existential stability, that his solution to the problem of relativism was destined to remain idiosyncratic (Schiffman 1991b, 76-77). Most importantly, it provided him with the opportunity and material for limitless literary and artistic creation. 


\section{NATURE IN EMERSON}

In his lectures and essays, Emerson ascribes divine attributes to nature. In his essay written in 1836, entitled "Nature", he laid the foundation of transcendentalism, an intellectual movement he developed with a few other American thinkers and scholars, such as George Putnam, Frederic Henry Hedge, and later Margaret Fuller, Moncure Conway, Samuel Longfellow, and others. According to the transcendentalist worldview, the divine, or God, permeates nature in a pantheistic manner. Emerson writes that the universe is composed of Nature and Soul. He exclaims in a characteristic poetic manner that he becomes a "transparent eye-ball" and a "part of particle of God" (Emerson n.d.).

Similarly to Montaigne and Rousseau, Emerson attempted to distance himself from society, which creates artificial constructs, and to become more "natural". According to the merits an individual deserves, he placed the natural man beside the courageous man: "Every natural action is graceful. Every heroic act is also decent, and causes the place and the bystanders to shine. Ever does natural beauty steal in like air, and envelope great actions." (Emerson n.d.). By suffusing themselves in nature, people open themselves to the universal soul. This process is supposed to lead to a spirituality of the new age. For Emerson, the spirit and the nature are inseparable. "Every natural fact is a symbol of some spiritual fact. Nature is the symbol of spirit. The whole of nature is the metaphor of the human mind," he wrote (Emerson n.d.). Richardson (1999, 97), therefore, rightfully concludes that "Emerson's basic teaching is that the fundamental context of our lives is nature"

Kantian idealism, born in the Age of Enlightenment, the time when humanity was trying to finalize the disenchantment of the divine providence and replace it with the realism of the rational being, contributes to the increasing shift toward anthropocentricism by giving every human being the power to create reality. Emerson argues: "In my utter impotence to test the authenticity of my senses, to know whether the impressions they make on me correspond with outlying object, what difference does it make, whether Orion is up there in heaven, or some god paints the image in the firmament of the soul?" (Emerson n.d.). Kant's influential view of perception as entirely subjective was supposed to reconcile the rationalists' contention about the existence of "innate ideas" with the empiricists' reliance on our senses for knowledge, but perhaps its most lasting contribution was the endorsement of individualism and personal sovereignty. Philosophers after Kant have continuously sought more freedom from the constraining authority of the state and the church and from the subsequent subjugation to the norm.

Kant also finds reason and rationale for ethical behavior outside of the biblical imperative (Kant 2012). As Taylor $(2005,8)$ holds that Kantian morals are most distinct in arguing that we have the power to make the laws by which we live, and that morality must be an autonomous force within us, we have to create our moral codes, based on ratio. Emerson $(1954,76)$ argues that the moral sentiment, found in all human beings, is the essence of all religions. And, as Richardson (1999, 103) explains: "Nature was Emerson's starting point for a new theology". By following transcendentalism and naturalism, Emerson paved the way to the general trends of secularization and individualism representative of the new spirit of the New World.

Emerson believed in reshaping the divine into something large and visible, which he referred to as nature. This worldview, in which one perceives new God suffused in nature, and becomes one with one's own surroundings, was the basis of his transcendentalism. By referring to nature as "the Universal Being", Emerson deified it in the manner of modern 
scientific-minded thinkers, who relativism truth by leaving its assessment to personal judgment and by placing it within the individual perception. If we are to become nature's darlings, "the great, the strong, the beautiful", though, "if we will be strong with [Nature's] strength" (Emerson 1950, 352), we must not believe in hocus-pocus, obsolete dogmas that constrain the body and the soul, but instead should rely on our rational souls that have the power to create wonderful things worthy of the new age and the opportunities that the freedom in the new country offers. Emerson thought that the Copernican astronomy had made the theological scheme of redemption absolutely unacceptable. "I regard it as the irresistible effect of the Copernican astronomy to have made the theological scheme of redemption absolutely incredible", Emerson $(1964,26)$ wrote.

The Logos, i.e. the word, which Emerson abandons, is replaced in his world view by nature. "Nature is the vehicle of thought," he explains, so, for him nature is language (Richardson 1999, 100). Emerson's long-term Endeavour was to demonstrate how the laws and processes of nature are a part of mind, and to solve and explain the relations between mind and external nature. Emerson was, according to Richardson (1999, 101), a naturalist of mental, not physical facts. Around 1848, he started working on a life-long project he called "Natural History of Intellect."

In his essay "The Beginnings of American Naturalism in our own Backyard", Popejoy (2014) argues that Emerson is the founder of American naturalism and one of the founders of global naturalism, which views nature as a source of three primary objects of ancient philosophy: Truth, Goodness and Beauty. He also connects Emerson to the roots of today's environmentalism and conservation of nature (Popejoy 2014). When one imbues the entire nature with spirit, this should purport a bit more than mere restraint from polluting the environment. Since Emerson is "the student of Eastern Philosophy" (Cavell 2003, 24), and in Buddhism and Hinduism one aspires to achieve ultimate harmony with nature, this argument can be seen as a legitimate. Buddhists in the West, in fact, see their religion as a valuable voice in the present ecological crisis, and they have founded a movement called Ecodharma, an ecological expression of Buddha's teachings. We may not take this idea relevant for the argument, but the fact remains that by moving away from the European religious tradition with his view of nature as a living organism perpetuating eternal presence and of humans as individual, rational beings, Emerson created a particular synthesis of American self-reliant pragmatism and New Age spirituality.

One could see Emerson's idealist vision of nature as an alternative to a disenchanted view of "brute" nature, rather than a step leading to it, which is an alternative well suited to today's concerns about sustainability in light of exploitation policies facilitated by conceptions of nature as insensible and inert. Although this is the most appropriate impression from the present perspective, contemporary environmentalists, nonetheless, do not have a radically different worldview than those polluting the environment. An overwhelming majority of eco-activists are liberal and not suspicious of the benefits of human social progress, while the roots of the ecological crisis really date back to the Middle Ages, as Marangudakis $(2001,248)$ explains. The newly Christianised barbarian tribes in Medieval Western Europe, he argues, cherished individuality, warfare and initiative. They preferred individual action to submission over "passive" contemplation practiced in the East. They favored "doing" God's will over "experiencing" it (Marangudakis 2001, 248). This view of man as the absolute master of creation was amplified during Renaissance Humanism, by the mercantile policies which became even more acute with the rise of industrial capitalism. In order to cure the devastating pollution of the environment, it is not 
enough to mitigate or reverse the process, but to change the general attitude that made the exploitation of nature for profit even possible. In Emerson's time, the ecological crisis was still far ahead, but, in spite of his proclivity to idealism and introspection, it is obvious that, being in strong favor of self-reliance, he was more a man of action than of passive contemplation.

\section{CONCLUSIONS}

Naturalism, as discussed above, does not suggest so much the love of, concern for or interest in nature, nor does it describe the literary approach primarily based on emotionless observation. Rather, it carries metaphorical connotations. In the past five hundred years, the concept of nature has gradually replaced the hitherto unprecedented authority of God the Creator. In the Renaissance, people engaged in the curious investigation of God's creation and its laws. Until the nineteenth century, the tendency to assign the wonders of existence to an impersonal, nondescript, ambiguous force called nature became pervasive. Richardson (1999, 104) explains that Emerson believed, like Marcus Aurelius and Montaigne, that nature rather than tradition or authority or the state is our best teacher. By placing man in the centre of nature, the Universal Being, as both Montaigne and Emerson did, Biblical authority is rejected and an autonomous being as the only individual responsible for judging things as right or wrong is constructed. This newly found liberty is the key for unlocking the world of endless possibilities for creation and enjoyment.

\section{REFERENCES}

Cavell, Stanley. 2003. Emerson's Transcendental Etudes. Stanford, CA: Stanford UP.

Courbet, Ernest and Charles Royer, (eds.) 1872-1900. Les Essais. Vol. 5.Paris: A. Lemerre.

Emerson, Ralph Waldo. 1950. “Experience.” In Selected Writings of Ralph Waldo Emerson. edited by Brooks Atkinson, 342-65. New York: Random House.

Emerson, Ralph Waldo. 1964. In Journals and Miscellaneous Notebooks, vol. 4, edited by Wm. H. Gilman et al. Cambridge, MA: Harvard UP.

Emerson, Ralph Waldo. 1995. "Montaigne, or, the Skeptic." In Representative Men. New York: Marsilio Publishers, 101-127.

Emerson, Ralph Waldo. n.d. "Nature". American Transcendentalism Web. [Accessed February 8, 2019] http://transcendentalism-legacy.tamu.edu/authors/emerson/essays/naturetext.html.

Hoffman, George. 2002. "Anatomy of the Mass: Montaigne's Cannibals"”. PMLA 117.2: 207-221.

Hoffmann, George. 2006. "The investigation of nature”. In The Cambridge Companion to Montaigne, edited by Ullrich Langer, 163-82. Cambridge, UK: Cambridge UK.

Kant, Immanuel. 2012. Groundwork of the Metaphysics of Morals. Cambridge, UK: Cambridge UP.

Marangudakis, Manoussos. 2001. "The Medieval Roots of Our Ecological Crisis". Environmental Ethics 23: 243-260.

Mikics, David. 2003. The Romance of Individualism in Emerson and Nietzsche. Columbus, OH: Ohio UP.

Montaigne, Michel de. 2002-3. Essais. 3 Vols. Paris: Gallimard.

Popejoy, Michael. 2014. Harvard University. Available at: https://green.harvard.edu/news/beginningsamerican-naturalism-our-own-backyard. [Accessed May 1, 2017]

Richardson, Robert D. Jr. 1999. "Emerson and Nature". In The Cambridge Companion to Ralph Waldo Emerson, edited by Joel Porte and Saundra Morris. Cambridge, UK: Cambridge UP.

Schiffman, Zachary Sayer. 1991a. On the Threshold of Modernity: Relativism in the French Renaissance. Baltimore: Johns Hopkins UP. 
Schiffman, Zachary Sayer. 1991b. "Humanism and the Problem of Relativism". In Humanism in Crisis: The Decline of the French Renaissance, edited by Philippe Desan, 69-85. Ann Arbor, Michigan: University of Michigan Library.

Shirmeister, Pamela. 1995. Introduction. Representative Men. New York: Marsilio Publishers. ix-xxxviii.

Taylor, Charles. 2005. A Secular Age. Cambridge, MA: Belknap.

Zalloua, Zahi. 2003. "Sameness and Difference: Portraying the Other in Montaigne's 'De l'amitié' and 'Des cannibales"”. Montaigne Studies 15: 177-190.

\section{PRIRODA KOD MONTENJA I EMERSONA}

Ralf Valdo Emerson je bio veliki poštovalac Mišela de Montenja, svog francuskog prethodnika, na koga se ugledao u sadržini i stilu svojih eseja. Štaviše, moglo bi se čak tvrditi da je Montenj uticao i na Emersonov pogled na svet. Jedna od oznaka koju bi obojica mogli dobiti u smislu teorijskog pogleda na svet jeste naturalista. Kritičari obojicu nazivaju naturalistima, ali njihov naturalizam nikad nije povezivan sa njihovim filosofskim ubeđenjima. I Montenj i Emerson hvale prirodu i sve „prirodno“, uključujući i ljudsku jedinku, $i$ vide prirodu kao prožetu svemogućim duhom. Pod uticajem pesnika i filozofa antike, njegovih intelektualnih učitelja, Montenj koristi reči „priroda“ $i$ „Bog" naizmenično, a Emerson dodeljuje prirodi božansku suštinu. Oba renomirana pisca na taj način doprinose jednom vidu skidanja vela tajne sa sveta $i$ depersonalizaciji obožavanog Tvorca.

Ključne reči: Montenj, Emerson, priroda, naturalizam 